\title{
Mullerian Inhibiting Substance: A Gonadal Hormone with Multiple Functions*
}

\author{
MARY M. LEE AND PATRICIA K. DONAHOE
}

Pediatric Surgical Research Laboratory, Pediatric Endocrine Unit (M.M.L.), and Pediatric Surgical Services

(P.K.D.), Massachusetts General Hospital, Boston, Massachusetts 02114

I. Summary

II. Introduction

III. Biology of MIS
A. Protein and gene structure
B. Processing and activation
C. Mechanism of action
D. Hormonal regulation
E. Gene regulation
F. Receptor characterization

IV. Physiological Functions of MIS
A. Mullerian duct regression
B. Germ cell maturation and gonadal morphogenesis
C. Lung maturation
D. Testicular descent
E. Growth inhibition of transformed cells

V. Clinical Applications for Serum MIS Measurements

A. Evaluation of intersex disorders

B. Tumor marker

VI. Conclusion

\section{Summary}

$\mathrm{M}$ ULLERIAN inhibiting substance (MIS) is the gonadal hormone that causes regression of the Mullerian ducts, the anlagen of the female internal reproductive structures, during male embryogenesis. MIS is a member of the large transforming growth factor- $\beta$ (TGF $\beta$ ) multigene family of glycoproteins that are involved in the regulation of growth and differentiation. The proteins in this gene family are all produced as dimeric precursors and undergo posttranslational processing for activation, requiring cleavage and dissociation to release bioactive $\mathrm{C}$-terminal fragments. Similarly, the 140 kilodalton ( $\mathrm{kDa}$ ) disulfide-linked homodimer of MIS is proteolytically cleaved to generate its active C-terminal fragments. The sexually dimorphic expression of MIS in Sertoli cells of the testis and granulosa cells of the ovary is critical for normal differentiation of the internal reproductive tract structures. A number of extra-Mullerian functions such as control of germ cell maturation and gonadal morphoge-

\footnotetext{
Address requests for reprints to: Mary M. Lee, M.D., Pediatric Surgical Research Laboratory (WRN-1133), Massachusetts General Hospital, 32 Fruit Street, Boston, Massachusetts 02114.

* Aided by Basic Research Grant 1-FY92-0426 from the March of Dimes Birth Defects Foundation (to M.M.L.) and by NIH Grants DK02129 (to M.M.L.) and CA-17393 (to P.K.D.)
}

nesis, induction of the abdominal phase of testicular descent, suppression of lung maturation, and growth inhibition of transformed cells have also been proposed for this growthinhibitory hormone and will be discussed. This article will summarize the current understanding of the biology and multiple functions of MIS including its activation, regulation, and mechanism of action and discuss areas of interest in ongoing research.

\section{Introduction}

Professor Alfred Jost first proposed that a testicular factor distinct from testosterone causes regression of the Mullerian ducts during male embryonic development (1). This hormone, termed Mullerian Inhibiting Substance (MIS), was subsequently identified as a growth-inhibitory glycoprotein related to the TGF $\beta$ s, inhibins, and activins (2). In the $50 \mathrm{yr}$ since the "Mullerian inhibitor" was first postulated, MIS, also known as anti-Mullerian hormone (3), has been purified, cloned, and recombinantly produced (4-7), and a recently isolated candidate receptor gene is being characterized. Much has been learned about its regulation and mechanism of action $(2,5,8-10)$, including evidence that MIS is tightly regulated in the SRY switch for sexual dimorphism, and that both primary and secondary cleavages are required for activation $(11,12)$. These new findings will affect the biological functions of MIS and the molecular mechanisms by which MIS exerts its effects on cell cycle kinetics and cellular differentiation.

Early in mammalian fetal development, the gonads are bipotential and both Mullerian and Wolffian ducts are present in the urogenital ridge: the former are the anlagen of the uterus, Fallopian tubes, and upper third of the vagina, and the latter are the embryologic precursors of the epididymis, vas deferens, and seminal vesicles $(1,13)$. The Mullerian ducts of both male and female embryos are transiently responsive to MIS during development, then lose their sensitivity after this critical period $(3,13)$. During embryogenesis in males, MIS causes involution of the Mullerian ducts while testosterone stimulates differentiation of the Wolffian ducts, whereas in females the Mullerian ducts differentiate spontaneously in the absence of MIS, while the Wolffian ducts involute in the absence of testosterone. MIS continues to be produced by Sertoli cells even after regression of the Mullerian ducts is complete; expression in the testes remains high after birth, then decreases markedly thereafter to the low 
levels found at puberty (14-17). Furthermore, ovarian production of MIS starts postnatally and is highest in the pubertal and adult ovary $(15,18-20)$. The secretion of MIS by the ovary, and by the testis after Mullerian duct regression is complete, is suggestive of additional extra-Mullerian biological functions for MIS. Other potential roles for this unique growth-inhibitory hormone include control of germ cell and gonadal differentiation $(21,22)$, induction of the abdominal phase of testicular descent $(8,23,24)$, suppression of lung maturation $(25,26)$, and growth inhibition of transformed cells $(4,27-30)$. We will summarize the current understanding of the biology of MIS, including its regulation, mechanism of action, and recently elucidated extra-Mullerian functions. We will also review the clinical applications for measurement of serum MIS. Much of the material that has been discussed previously will not be presented in detail.

\section{Biology of MIS}

\section{A. Protein and gene structure}

MIS is a member of a large multigene family of glycoproteins involved in the regulation of growth and differentiation $(31,32)$. The proteins in this gene family, the TGF $\beta$ s $(33)$, inhibin (34), activins $(35,36)$, Xenopus Vg-1 $(37)$, Drosophila decapentaplegia complex (38), and bone morphogenesis factors (39), have C-terminal homology, particularly around seven highly conserved cysteine residues (31). Many of these proteins are produced as dimeric precursors that undergo similar posttranslational processing for activation, requiring cleavage and dissociation to release disulfide-linked bioactive C-terminal fragments $(12,29,31)$.

The highly conserved MIS proteins are synthesized as 553 (rat) to 575 (bovine) amino acid precursors, with short amino acid leader sequences consisting of a signal peptide and a putative pro-sequence predicted by von Heijne analysis (Fig. 1) (40). Across species, MIS has 11 to 12 conserved cysteines, of which seven are in the C-terminal domain. The C-terminus has the strongest homology, with 108 of the last 112 amino acids conserved between the bovine and human protein, and 104 of 112 amino acids conserved between the rat and human protein. The least conserved amino acids in the $\mathrm{C}$-terminus are the ones surrounding the primary cleavage site.

Genomic and/or complementary DNA clones have been isolated for human (41), bovine (41), rat (42), and mouse (43) MIS. The MIS genes have similar intron/exon structures with a high GC content of $72 \%$ in the five exons and $68 \%$ in the introns and flanking regions. The bovine, human, and rat genes have $65-80 \%$ nucleotide homology across the coding regions and $70-75 \%$ homology in the promoter regions. The 5 '-untranslated regions contain only 10 (bovine and human) or 8 (mouse and rat) nucleotides, and therefore are unlikely to exert translational control, but could function as transcriptional regulatory elements. The $3^{\prime}$-untranslated regions of MIS are also relatively short, from 62 nucleotides in the rat to 112 in humans. The human MIS gene has been mapped to chromosome 19, p13.2-13.3 (44) and the mouse MIS gene to chromosome 10 (45).
Recent studies indicate that rat MIS has two developmentally regulated messenger RNA transcripts that are differentially polyadenylated (46). A larger 2.0 kilobase species is abundant by day 14 in embryonic testes, then decreases markedly at birth, and is barely detectable postnatally. A smaller 1.8 kilobase species is detectable at embryonic day 18 , and prominent at day 21 , then decreases markedly, but remains detectable postnatally. Although the biological significance of the two transcripts is not known, the differential polyadenylation may affect the stability or translatability of the two mRNAs as described for other systems (47).

\section{B. Processing and activation}

The early methods of purification of MIS from bovine testes by sequential diethylaminoethyl ion exchange, dyeaffinity, or immunoaffinity chromatography yielded partially purified preparations of MIS that remain biologically active in the organ culture assay as well as in the antiproliferative assays (48). Currently MIS is recombinantly produced in Chinese hamster ovary $(\mathrm{CHO})$ cells transfected with the human MIS gene driven by the SV40 early promoter $(4,41)$. Recombinant human MIS (rhMIS) is highly purified from conditioned media by immunoaffinity chromatography using a mouse monoclonal antibody to MIS $(7,49)$. Elution of immunoaffinity-purified rhMIS with either $1 \mathrm{~m}$ acetic acid or $2 \mathrm{M}$ NaSCN yields MIS preparations that are $90-95 \%$ purified and active in the bioassay but with variable activity in the antiproliferative assays (49). Addition of a salt wash step with $0.5 \mathrm{~m}$ sodium chloride before the acid elution, however, results in the removal of a low molecular weight triplet that has growth-promoting effects (11). These proteins are not recognized by MIS antibodies and are also present in media from wild-type $\mathrm{CHO}$ cells. MIS purified after this pre-elution salt wash retains both antiproliferative activity and Mullerian duct regression bioactivity $(27,30)$.

Mature MIS undergoes glycosylation and dimerization and is secreted as a 140 kilodalton $(\mathrm{kDa})$ dimer of two identical disulfide-linked subunits $(2,9,50)$. Two presumptive $\mathrm{N}$ linked glycosylation sites are found in the $\mathrm{N}$-terminal portion of the molecule (Fig. 1), one of which is not conserved in the rat. Their role in the processing or mechanism of action of MIS remains to be determined as removal of $\mathrm{N}$-linked complex carbohydrates with endoglycosidase $\mathrm{F}$ does not result in loss of bioactivity (2). On reducing sodium dodecyl sulfatepolyacrylamide gels, MIS has an electrophoretic pattern consisting of a major doublet at $70 \mathrm{kDa}$ and primary cleavage products at 57 and $12.5 \mathrm{kDa}(11,12)$. Plasmin treatment results in more complete cleavage of MIS to its $57 \mathrm{kDa} \mathrm{N}$ terminal and $12.5 \mathrm{kDa}$ C-terminal fragments. Amino acid sequence analysis indicates that MIS is cleaved between Arg 427 and Ser 428 near its $C$ terminus (Fig. 1), at a position similar to the cleavage sites of other members of this gene family. The amino acids surrounding the MIS Arg-Ser site, however, resemble a monobasic consensus cleavage site (51) rather than the dibasic or tetrabasic site present in the TGF $\beta$ gene family (31). When plasmin-treated preparations of MIS are immunoaffinity-purified with a monoclonal antibody specific for the $\mathrm{N}$ terminus, the $\mathrm{C}$-terminal dimer co-purifies 
Fig. 1. Primary amino acid sequence of human MIS. A 24 amino acid leader (pre-pro) sequence is cleaved to generate the 536 amino acid mature protein, which then undergoes proteolytic processing for activation. Primary cleavage of human MIS at arginine 427 (arrow) yields the predominant $57.5 \mathrm{kDa} \mathrm{N}$ - and $12.5 \mathrm{kDa}$ C-terminal fragments. Secondary cleavage of MIS occurs at arginine 229 (arrow) of the $\mathrm{N}$-terminal moiety to yield 34 and $22 \mathrm{kDa}$ fragments. The two $\mathrm{N}$-linked glycosylation sites (double arrowheads), the leucine repeats surounding the primary cleavage site (black boxes), and the seven cysteines that are conserved in the TGF $\beta$ family (open circles) are delineated.
Pre-Pro Sequence

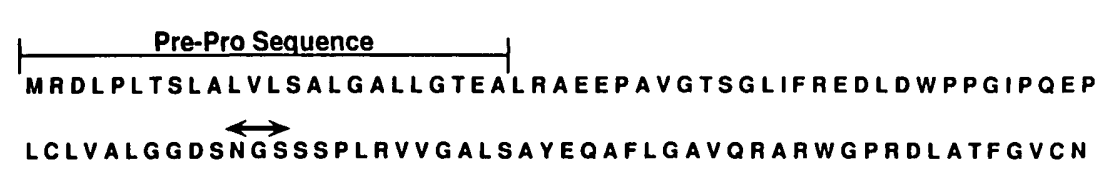

TGDRQAALPSLRRLGAWLRDPGGQRLVVLHLEEVTWEPTPSLRFQEPPPGGA GPPELALLVLYPGPGPEVTVTRAGLPGAQSLCPSRDTRYLVLAVDRPAGAWR GSGLALTLQPRGEDSRLSTARLQALLFGDDHRCFTRMTPALLLLPR SEPAPL

PAHGQLDTVPFPPPRPSAELEESPPSADPFLETLTRLVRALA VPPARASAPR

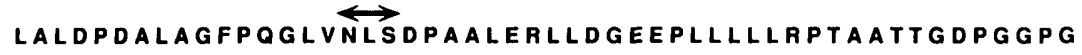

PAPLHDPTSAPWATALARRVAAELQAAAAELRLLGLPPATAPLLARLLAL

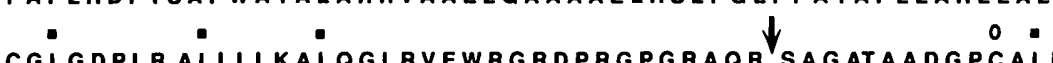

TRGPGAQR SAGATAADGPCALR

ELSVDLRAERSVLIPETYOANNCQGVCGWPOSDRNPRYGNHVVLLLKMQA 00 $\begin{array}{lll}0 & 0\end{array}$

RGAALARPPCCVPTAYAGKLLISLSEERISAHHVPNMVATECGCR with the $\mathrm{N}$-terminal dimer, indicating that the fragments remain in noncovalent association $(2,29)$. The cleaved dimeric complex remains active in the bioassay when dissociated with $1 \%$ sodium deoxycholate, but unlike the TGF $\beta$ s, loses activity when dissociated with prolonged acidification or boiling (12). When Arg 427 at the primary cleavage site is converted to threonine by site-directed mutagenesis, the mutated MIS is noncleavable and inactive in the organ culture assay, confirming that proteolytic processing of MIS is obligatory for full bioactivity $(2,12)$. Prolonged exposure of MIS to plasmin results in further proteolysis of the $57 \mathrm{kDa}$ $\mathrm{N}$-terminal moiety, generating 34 and $22 \mathrm{kDa}$ fragments (11). By amino acid sequence analysis, this secondary cleavage site is probably at Arg 229-Ser 230.

The $\mathrm{N}$ - and C-terminal cleavage products of holo-MIS have been separated and isolated by column chromatography after plasmin cleavage of holo-MIS and tested for activity individually in the various assays $(29,51 \mathrm{a})$. The $25 \mathrm{kDa}$ $\mathrm{C}$-terminal dimers are consistently active in the organ culture assay, whereas the $110 \mathrm{kDa}$-terminal dimers are inactive. The bioactivity of the C-terminal fragment is not enhanced by the addition of $\mathrm{N}$-terminal dimers in our quantitative bioassay (29) although rapid aggregation of the isolated fragments makes it difficult to assess their stoichiometric roles in MIS action. In a nonquantitative organ culture assay, the $\mathrm{N}$-terminal domain appears to potentiate the effects of the $\mathrm{C}$-terminus (51a). When tested in an antiproliferative assay, the C-terminal fragments inhibit proliferation of A-431 cells while the solubilized $\mathrm{N}$-terminal fragments isolated from the same starting material fail to suppress growth at equimolar concentrations (29). Again $\mathrm{N}$ - and C-terminal fragments added together did not have enhanced activity. The Cterminal fragment is also the active moiety in a bioassay that measures the ability of MIS to suppress aromatase activity in cultured rat ovaries although addition of either N-terminal fragments or FCS enhances the effect (51a). These data confirm that the Mullerian duct regression bioactivity and antiproliferative activity of MIS reside primarily in its Cterminal domain. The variable activity of holo-MIS preparations in the different assays may be attributable to an endogenous protease present in some of the systems, such as the organ culture assay, but not in others.

\section{Mechanism of action}

Although the molecular mechanism of action of MIS has not been fully elucidated, it is thought to involve receptormediated dephosphorylation $(10,52)$. A potential interaction between MIS and epidermal growth factor (EGF) was investigated after similarities were noted between MIS and a membrane-bound phosphotyrosyl protein phosphatase that reverses EGF-stimulated phosphorylation (53). This phosphatase is activated by EDTA and fluoride and inhibited by zinc and vanadate. Similarly fluoride and EDTA mimic, and zinc and vanadate antagonize, the effects of MIS on the Mullerian duct $(52,54)$. EGF, with $1 \mathrm{~mm}$ manganese as a cofactor, was therefore tested in the organ culture assay and found to inhibit MIS-stimulated ductal regression. Nerve growth factor and fibroblast growth factor as well as other mitogens with receptor tyrosine kinase activity, such as insulin and platelet-derived growth factor, did not affect MIS activity, indicating that the interaction between MIS and EGF is specific $(5,52)$. Bovine MIS was later found to inhibit colony formation of an EGF receptor-rich vulvar carcinoma cell line (A-431) that requires EGF for growth in soft agar $(55,56)$. Bovine MIS inhibits EGF- induced membrane tyrosine phosphorylation in this cell line without competing for EGF receptor binding sites or diminishing the phosphorylation of prelabeled EGF receptors. MIS and EGF also have opposing effects on EGF receptor autophosphorylation in fetal rat lung fibroblasts (57) and on germinal vesicle breakdown in the oocyte, which is inhibited by MIS and stimulated by EGF (58). Thus EGF and MIS have opposing effects on cellular growth and differentiation in a number of systems. 
Another example of a growth inhibitor that antagonizes growth factor-stimulated tyrosine phosphorylation is the 63 $\mathrm{kDa}$ phosphoprotein, derived from conditioned media of liver tumor cells, that has partial sequence homology to MIS (59). This phosphoprotein inhibits the growth and insulinstimulated insulin receptor autophosphorylation of liver cells.

A clue to the mechanism of action for MIS was suggested by the recent cloning and identification of activin (60) and TGF $\beta$ type II receptors (61) as serine-threonine kinases. The MIS receptor is likely to be a member of this same receptor family and may have similar functional properties (W. W. He, M. L. Gustafson, and P. K. Donahoe, unpublished data). Complete characterization of the MIS receptor will permit a fuller understanding of the molecular action of MIS and will help to delineate the molecular basis for the opposing actions of MIS and EGF.

\section{Hormonal regulation}

The hormonal regulation of MIS has been examined in both animal models and tissue culture systems. Testes from neonatal Sprague-Dawley rats treated with LHRH antiserum in utero had greater MIS bioactivity than testes from vehicletreated rats (62). Treatment of the newborn pups with FSH for 5 days after birth reversed this effect, while human CG (hCG) had no effect, indicating that the hypothalamic-pituitary-gonadal axis via FSH has a role in the regulation of MIS (63). More recent observations confirm the role of FSH in the regulation of MIS. After twice daily injection of newborn rats with either gonadotropins or vehicle, the testes of FSHtreated animals had less MIS mRNA and immunoreactive protein than those of LH- or vehicle-treated animals (Fig. 2) (17). By the 5 th postnatal day, MIS immunoreactivity had decreased to low constitutive levels in the controls that were indistinguishable from FSH-treated animals. Similar results were obtained in embryos harvested at day 21, 2 days after in utero injection on day 19 with gonadotropins or vehicle (64). These data confirm the inhibition of MIS by FSH and show that this modulation is transcriptionally mediated.

The latter study also examined the effects of gonadotropins and sex steroids on MIS expression by immunohistochemical staining with antibodies specific for the $\mathrm{N}$ - and C-terminal fragments as well as holo-MIS (64). Paradoxically, the testes of testosterone and hCG-treated fetuses had unchanged or slightly decreased immunostaining for holo-MIS, but increased staining with the $\mathrm{N}$ - and C-terminal antibodies. No differences were noted in mRNA levels. Consequently, we hypothesize that testosterone and hCG/LH, in contrast to FSH, regulate MIS posttranslationally by enhancing the processing of holo-MIS to its $\mathrm{N}$ - and C-terminal fragments.

Several attempts to study the effects of FSH on cultured cells have been hindered by the progressive decline in the synthesis of MIS in primary cultures of Sertoli cells $(65,66)$. An increase in CAMP concentrations in the culture media of Sertoli cells and testicular tissue fragments after FSH treatment could be demonstrated, but MIS mRNA and protein concentrations in the media after treatment fell rapidly, regardless of the added constituents (66). In contrast to the down-regulation of MIS by FSH in neonatal rats, hCG and FSH had no effect on MIS mRNA levels in cultured human fetal Sertoli cells whereas $(\mathrm{Bu})_{2} \mathrm{CAMP}$ induces MIS mRNA 5fold (67). In cultures of adult human granulosa cells collected after hormonal stimulation for in vitro fertilization, MIS mRNA levels were induced 9 -fold by $(\mathrm{Bu})_{2} \mathrm{CAMP}$ and 5 -fold by hCG, but FSH, insulin, and progesterone had no effect
FIG. 2. FSH regulation of MIS expression. Newborn rats injected with FSH twice a day for 2 to 4 days have decreased immunoreactivity of MIS in the seminiferous tubules of the testes compared to vehicle-injected controls. The bar graph depicts the staining intensity in the seminiferous tubules of FSH- treated animals (shaded bars) compared to controls (open bars), as quantitated by computerized image analysis of intratubular staining minus interstitial background staining. [Reprinted with permission from Kuroda et al:: Endocrinology 127:1825-1832, 1990 (17). ${ }^{\circ}$ The Endocrine Society.]

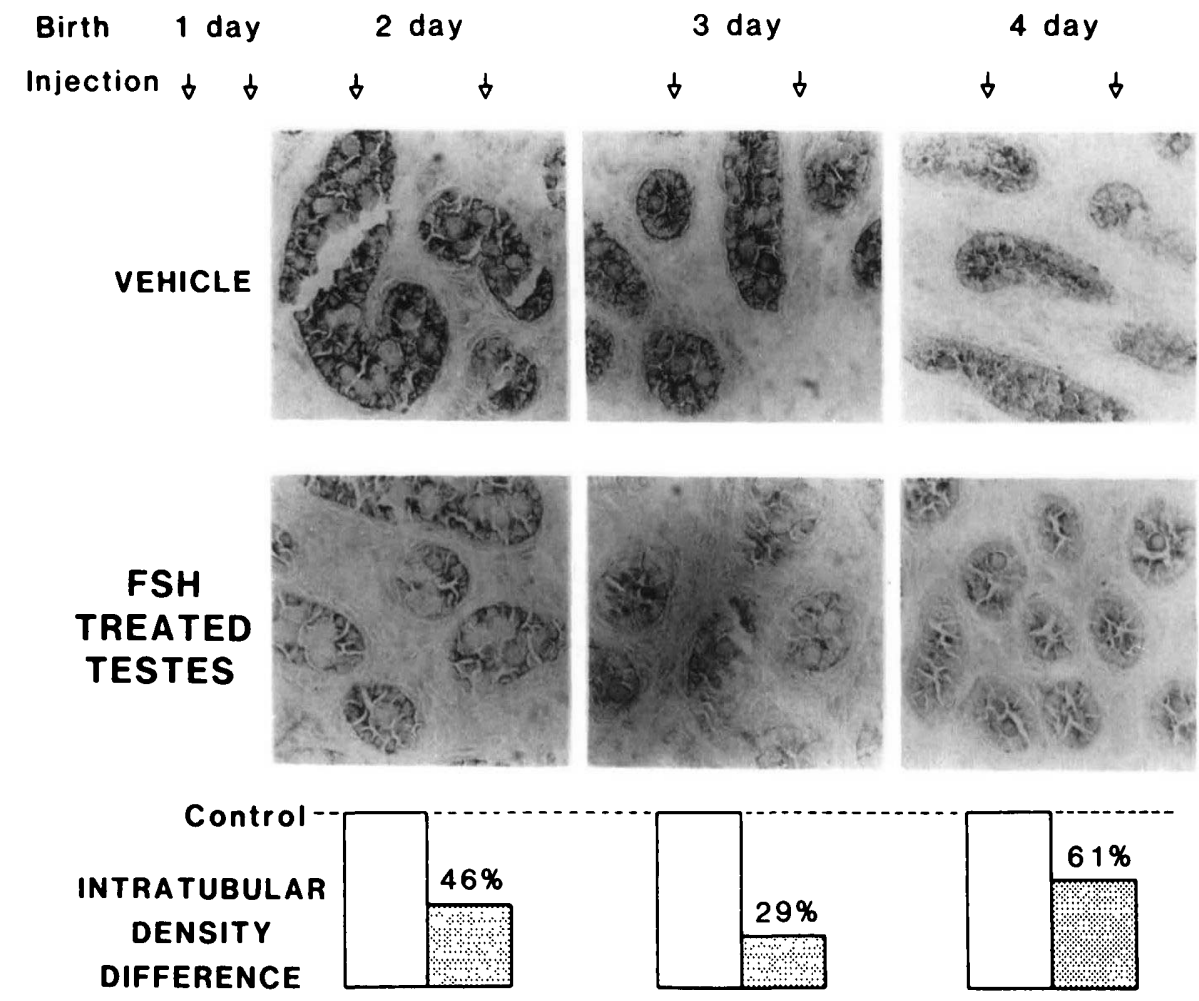


(67). Further studies of MIS regulation in vitro will be facilitated by the availability of cell lines that express MIS. These are currently being developed in our laboratory by manipulating culture conditions for Sertoli cells and by retroviral transfection of primary cultures and established cell lines.

\section{E. Gene regulation}

Identification and characterization of the trans-acting factors and cis-acting elements responsible for the tissue-specific and developmentally regulated expression of MIS are areas of active research interest. The promoters of the human, bovine, and rat genes are $75 \%$ homologous. Analysis of the 5 '-flanking sequences of the human and rat genes reveals sequences that are similar but not identical to known regulatory elements $(42,68)$. No functional role in MIS gene regulation, however, has been demonstrated thus far for any of these consensus regulatory sequences. A sequence with one mismatch for the cAMP-responsive element is present at -262 in the human but not the bovine or rat promoter region, although MIS expression is modulated by cAMP and FSH in the testes $(17,64,67)$ and by cAMP and LH in the ovary (67). The rat gene has a sequence at -301 , 5'TCAATTAAAC3', that resembles the consensus binding site $\left(5^{\prime}\right.$ TCAATTAAAT $\left.^{\prime}\right)$ for homeobox proteins such as fushi tarazu in the Drosophila ultrabithorax promoter. The significance of the canonical SP1 recognition sites (CCGCCC) found in the bovine and human MIS genes is unclear because of the high GC content in the MIS promoter. A 13 basepair sequence ( $5^{\prime}$ GGTCACAGGGACC $3^{\prime}$ ) that differs by one nucleotide from the estrogen response element (5'GGTCACAGTGACC $3^{\prime}$ ) of the vitellogenin gene is found at position $-177 \overline{2}$ in the human gene. Co-transfection of the estrogen receptor and this "ERE" inverted repeat as a 35 basepair oligonucleotide linked to a reporter gene confers estrogen responsiveness on a heterologous promoter (68). Nevertheless, the function of this element in vivo is unclear as similar experiments with an 182 basepair fragment of the MIS promoter encompassing the "ERE" and its flanking sequences fail to show estrogen inducibility (68).

Comparison of the rat, bovine, and human MIS genes reveals a number of other conserved sequences with no obvious similarities to known regulatory elements. Some of these repeated sequences contain regions of dyad symmetry and are postulated to have a role in the transcriptional regulation of MIS. Mobility shift assays using oligonucleotides (30-40 mers) containing these consensus regulatory elements exhibit numerous protein-DNA interactions ( $C$. Haqq and P. K. Donahoe, unpublished data). One repeated motif, 5'GGAGATAGG3', called M1, is conserved between rat, bovine, and human MIS and is similar to the repeated androgen-binding protein enhancer sequence, 5'GGAGAA3'. Although M1 binding exhibits the correct developmental pattern for MIS enhancer activity, it is not limited to testicular nuclear extracts. Thus, M1 does not confer tissue-specific expression but may be critical for basal MIS expression or may act in conjunction with other cisacting elements to direct tissue- or age-specific expression.

Another putative binding site, termed M2 (M2-5' and
$\mathrm{M} 2-3^{\prime}$ ), is found at -102 to -78 in the rat gene. $M 2-5^{\prime}$ is a unique sequence with dyad symmetry $\left(5^{\prime}\right.$ GCCAGGCACTGTC $3^{\prime}$ ). M2-3' (5'CCCAAGGTCA $\left.3^{\prime}\right)$ is repeated at -200 with one mismatch and again seven times between -600 to -900 . Mobility shift assays with M2 oligonucleotides show tissue- and sex-specific protein-DNA binding that is consistent with MIS expression in vivo except for low levels in nuclear extracts from the newborn male brain. Ovarian M2 binding proteins are lower in molecular weight than testicular proteins and have a different developmental pattern of expression.

The initial activation of MIS transcription during embryogenesis may be part of a hierarchal cascade of transcriptional events that regulate sexually dimorphic development. Because MIS is one of the earliest sexually dimorphic genes expressed during development, SRY, the putative testis determining gene, may be involved in initiating its transcription. In the mouse, Sry is expressed from days 10.5 to 12.5 postcoitus, when the undifferentiated gonad is forming aggregates of pre-Sertoli cells surrounding the germ cells (69). MIS expression is first detected at day 12.5 postcoitus in the mouse (43) and at the developmentally equivalent day 13.5 in the rat (70). The sequential timing of SRY and MIS expression is consistent with activation of MIS by SRY. The DNA binding domain of SRY has a conserved sequence motif shared by high mobility group transcription factors. This 80 amino acid domain, purified as a cleavable glutathione transferase chimeric protein, recognizes an upstream element (designated SRYe) in the promoter region of the MIS gene with nanomolar affinity and with tissue and developmental specificity (70a). Competitive binding experiments with the mutated binding element confirm the specificity of the binding. These results support the hypothesis that SRY and MIS are sequential elements in a genetic program that controls sexual dimorphism.

\section{F. Receptor characterization}

Characterization of the MIS receptor has been a challenging task. Although the complex mesenchymal and epithelial interactions observed during Mullerian duct regression (71) make it difficult to determine if MIS receptors are present in both epithelial and mesenchymal cells of the Mullerian duct, recent work indicates that MIS acts directly on mesenchymal cells and indirectly through the mesenchyme on epithelial cells (72). Consequently, the mesenchymal cells of the urogenital ridge may be the primary source of the receptor. The limited quantities of tissue available from urogenital ridges obtained at the appropriate embryonic stage has made it difficult to purify or biochemically analyze the receptor. Iodinated highly purified MIS binds specifically to A-431 cells (73) and to fetal rat lung fibroblasts (57); thus these two cell types may offer a more abundant source of MIS receptor than the minute amounts of mesenchymal tissue available from the fetal undifferentiated urogenital ridge.

Several molecular approaches are being used to isolate and clone the MIS receptor. Expression cloning using fluoresceinated or iodinated holo-MIS to screen urogenital ridge libraries has been unsuccessful because of difficulties in 
maintaining the biological activity of labeled MIS (M. L. Gustafson and P. K. Donahoe, unpublished data). Recent data showing that the C-terminal fragment is the biologically active moiety indicate that uncleaved holo-MIS is probably a poor ligand for expression cloning. The requirement for proteolytic cleavage of MIS to generate its active domain has focused our attention on the C-terminal fragment as the cognate ligand for the MIS receptor. Recent efforts to identify the MIS receptor by expression cloning have concentrated on screening with iodinated $C$ terminus. Specific binding has been difficult to detect and amplify, perhaps due to the low abundance of the MIS receptor or decreased activity of iodinated $C$ terminus.

Parallel efforts to isolate the MIS receptor have focused on on the likelihood that the MIS receptor is homologous to the recently cloned activin (60) and TGF $\beta 2$ receptors (61). These closely related receptors have a single membrane-spanning domain and are serine-threonine kinases. Degenerate oligonucleotide primers complementary to homologous regions of the activin and $\mathrm{TGF} \beta_{2}$ receptors have been designed for polymerase chain reaction amplification of the MIS receptor from an embryonic day 14 rat urogenital ridge cDNA library. A candidate clone for the MIS receptor has been identified and is currently being further characterized (W. W. He, M. L. Gustafson, and P. K. Donahoe, unpublished data). This putative MIS receptor has been localized to the mesenchymal cells surrounding the Mullerian duct and to the developing oocytes in preantral and antral follicles by in situ hybridization. The mRNA is detected by Northern analysis in developing testes and mature ovaries, as well as in cell lines that are growth-inhibited by MIS. Isolation of the MIS receptor gene will enable studies to be designed that will increase the understanding of the mechanism of action of MIS and delineate other extra-Mullerian functions of MIS. In the clinical setting, MIS receptor probes may be invaluable in preselecting patients with tumors sensitive to MIS or its congeners.

\section{Physiological Functions of MIS}

\section{A. Mullerian duct regression}

Mullerian duct regression occurs early in embryonic development. Pre-Sertoli cells in the undifferentiated gonad aggregate around the germ cells and form seminiferous cords by day 13 postcoitus in the rat. By the afternoon of day 13 , before testosterone is detected in Leydig cells, MIS mRNA and protein are detectable in the immature Sertoli cells (3, $20,70)$. By day 15 postcoitus, hyaluronidase activity is increased, and the extracellular matrix constituents, such as fibronectin, start to disappear as mesenchyme surrounds the duct, and dissolution of the duct begins $(54,71,74)$. By day 16 , the basement membrane has disappeared and hyaluronidase activity is lost. On day 17, the Mullerian duct is no longer visible and only mesenchymal cells remain. When 15.5 day gestation Mullerian duct epithelium is separated from the mesothelium and cultured separately with MIS, both cell types survive, although $\left.{ }^{3} \mathrm{H}\right]$ thymidine incorpora- tion is decreased in the mesothelial but not in the epithelial cells (72). These data reveal that MIS exerts its effects on the ductal epithelium via the surrounding mesenchyme. Human male fetal genital tracts have signs of ductal regression that are irreversible by 51 days postovulation (75). Coculture of the urogenital ridge of female fetuses less than $25 \mathrm{~mm}$ in crown-rump length with testicular tissue results in regression of the Mullerian duct, while the ducts of fetuses greater than $30 \mathrm{~mm}$ in crown-rump length are no longer responsive to MIS (3).

Picon (13) first developed an organ culture assay to moniter MIS bioactivity in vitro, a crucial step in advancing the study of this hormone. Fetal rat urogenital ridges were placed in organ culture for 3 days, then examined histologically for regression of the Mullerian duct. At 14.5 to 15.5 days postcoitus, the Mullerian ducts of both male and female rat fetuses are histologically similar and respond similarly in culture. Urogenital ridges obtained from older female fetuses have incomplete regression of the Mullerian duct when cultured with MIS, while the Mullerian ducts of older male fetuses involute in culture even in the absence of MIS. Thus, the sensitivity of the Mullerian ducts to the inhibitory effects of MIS depends primarily on the age of the urogenital ridge. Biochemical and cellular changes characteristic of ductal regression proceed irreversibly if exposure to MIS has occurred before 15 days, even if MIS is subsequently removed $(3,13,76)$. Conversely, ducts that have not been exposed to MIS by 15 days gestation no longer fully involute in response to the hormone.

Picon's organ culture assay has been modified to establish a graded bioassay in which 14.5 day female rat embryonic urogenital ridges are incubated with the tissue fragment, conditioned media, or biological fluid to be tested (Fig. 3) (76). To facilitate morphological comparison, testosterone is added to the media at $10^{-9} \mathrm{M}$ to enhance the effect of MIS and stimulate growth of the Wolffian duct (77). After $72 \mathrm{~h}$ incubation in humidified $5 \% \mathrm{CO}_{2}$, the specimen is sectioned and stained with hematoxylin and eosin. Regression of the Mullerian duct is graded from 0 (no regression) to 5 (complete regression) by at least two independent observers. The organ culture bioassay requires $1.5-2 \mu \mathrm{g} / \mathrm{ml}$ of recombinant holoMIS for full ductal regression. A similar assay has been established with the mouse urogenital ridge (14). Because of the differing sensitivity of the cephalic and caudal ends of the urogenital ridge to MIS, Josso and colleagues (3) quantitate ductal regression as "complete, near-complete, incomplete, and no regression" by assessing the extent (length) of the regression. The organ culture assay of Mullerian duct regression remains the most specific assay for MIS activity, against which all others are compared. An understanding of the regression of the Mullerian duct under these experimental conditions helps to clarify the conditions under which the Mullerian duct regresses in intersex abnormalities or fails to undergo regression in the persistent Mullerian duct syndrome.

Persistent Mullerian duct syndrome (PMDS) is a heterogeneous disorder, with evidence for both end-organ unresponsiveness to MIS despite normal production of the hor- 


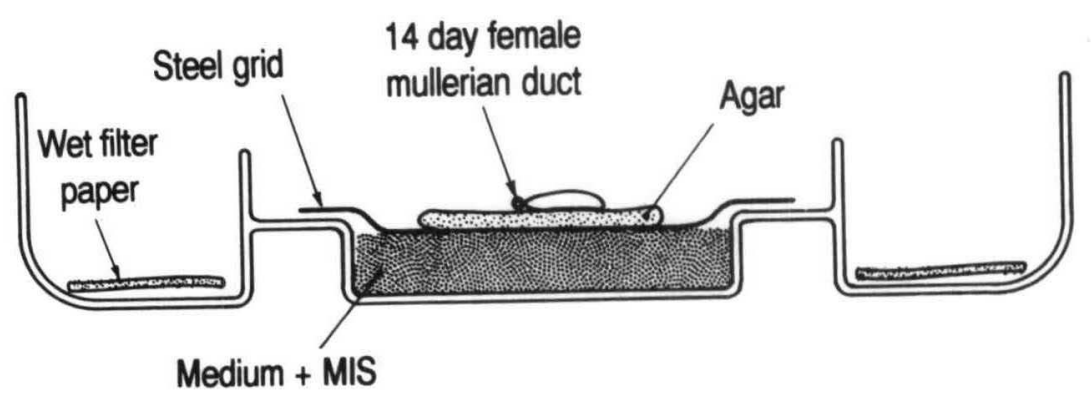

FIG. 3. The Mullerian duct organ culture assay for MIS. A schematic of the organ culture bioassay is shown above the histological sections of the urogenital ridge. Female Mullerian ducts are incubated on agar-coated stainless steel grids for $72 \mathrm{~h}$ at $37 \mathrm{C}$, then fixed, sectioned, and stained. Regression of the Mullerian duct $(M)$ is graded from 0 (no regression) to 5 (full regression) and can be contrasted with the testosterone-stimulated Wolffian duct (W). [Adapted with permission from Donahoe et al:: J Surg Res 23:141-148, 1977 (76).]

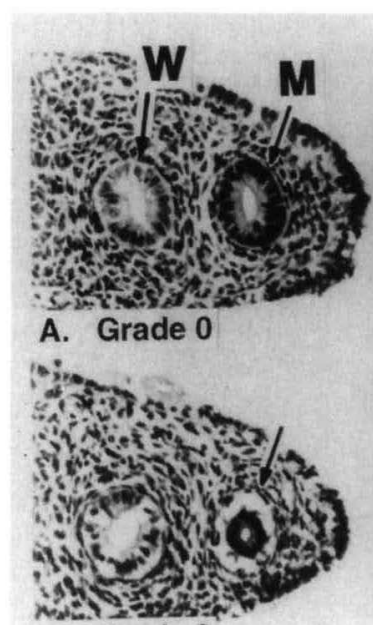

D. Grade 3

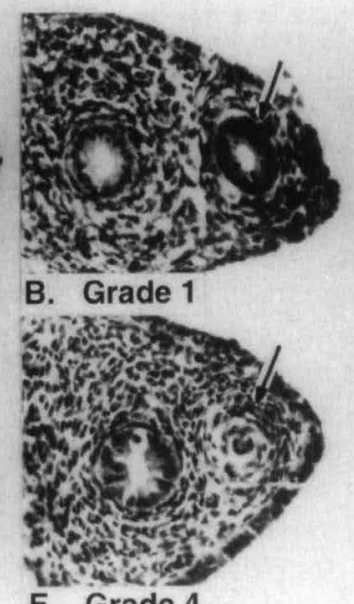

E. Grade 4

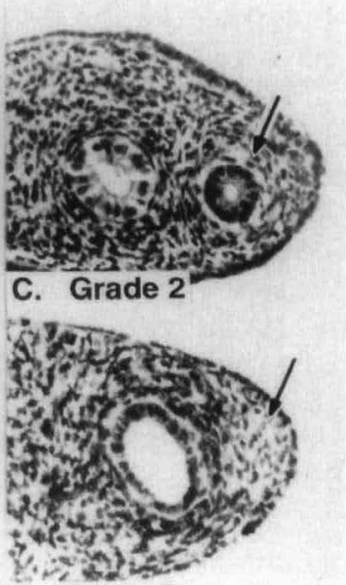

F. Grade 5 mone and deficiency of the bioactive hormone. A PMDS dog model that is carried as an autosomal recessive trait appears to result from peripheral resistance (receptor defect) rather than insufficient production of MIS $(78,78 \mathrm{a})$. The homozygous affected dogs and nonaffected dogs produce equivalent amounts of MIS $(78,78 a)$ that are bioactive in the rat urogenital ridge organ culture assay (78). The disorder in humans appears to be heterogeneous in etiology as patients may have either normal or absent serum MIS concentrations $(79,80)$. Testicular biopsies of five patients with PMDS revealed the presence of MIS mRNA in all of the specimens, although only two had bioactive MIS (81). The three patients who lacked bioactive or immunoreactive MIS were siblings who were subsequently found to have point mutations in the fifth exon of the MIS gene, which prematurely terminated translation, resulting in an unstable truncated protein (82). Additional patients with absent or bioinactive MIS are being studied for other mutations of the MIS gene. Identification of the MIS receptor gene will allow similar molecular analysis of PMDS patients with presumed receptor defects.

\section{B. Germ cell maturation and gonadal morphogenesis}

In addition to its well-defined role in male sexual differentiation, the ontogeny and function of MIS in the ovary have also been examined $(2,8,9)$. MIS has been detected in ovaries and follicular fluid of many species and is synthesized by the granulosa cells of the ovary. Bioactive MIS is first detected in rat ovaries 3 days after birth, when the rat oocyte becomes arrested in the dictyate or diffuse diplotene stage
$(20,70)$. In contrast to the generalized Sertoli cell pattern seen in the testis, MIS clearly localizes to granulosa cells in preantral and antral follicles but not to atretic or primordial follicles, or to the corpus luteum (Fig. 4) (83). In the cycling adult ovary, the same cells stain in preantral, antral, and preovulatory follicles throughout estrus, metestrus, diestrus, and early proestrus. In late proestrus, as progesterone levels rise just before ovulation when the oocyte resumes meiotic division, the staining in the preovulatory follicles wanes. In situ hybridization shows that MIS MRNA is abundant in granulosa cells surrounding preantral and small antral follicles and most prominent in cells proximal to the follicular lumen (70).

Observations of abnormalities in sexual differentiation and development caused by inappropriate expression of MIS led to hypotheses about other functions of MIS in the reproductive system. Premature exposure of the female fetus to MIS during early embryogenesis causes agenesis of the Mullerian structures and an "endocrine sex-reversal" of the ovaries (22, $84,85)$. Immature ovaries cultured with MIS have decreased aromatase activity, resulting in increased testosterone synthesis (85). The ability of MIS to change the sex steroid secretion of immature ovaries may explain the virilization and seminiferous tubule formation in ovaries of freemartin calves that are exposed to MIS in utero and is consistent with the hypothesis that the appropriate expression of MIS is important in gonadal differentiation. The absence of MIS is critical for normal ovarian steroidogenesis, and the presence of MIS in the immature testes may enhance testosterone 
Fig. 4. MIS protein and mRNA in the rat ovary. Immunohistochemical staining of the 21 day (A) and 27 day (B) ovary shows more intense immunoreactivity of the inner granulosa cells and cumulus cells of the preantral (PAF) and smaller antral (AF) follicles than that of larger antral follicles (S and T). $(\times 200)$. Lightfield (C) and darkfield (D) in situ hybridization of the 21 day ovary demonstrates MIS mRNA in the granulosa cells surrounding preantral (PAF) and antral (AF) follicles but not in atretic follicles (ATR). [Adapted with permission from Ueno et al:: Endocrinology 131:854-862, 1989 (70) and Hirobe et al.: Endocrinology 124:1000-1006, 1992 (83). -The Endocrine Society.]
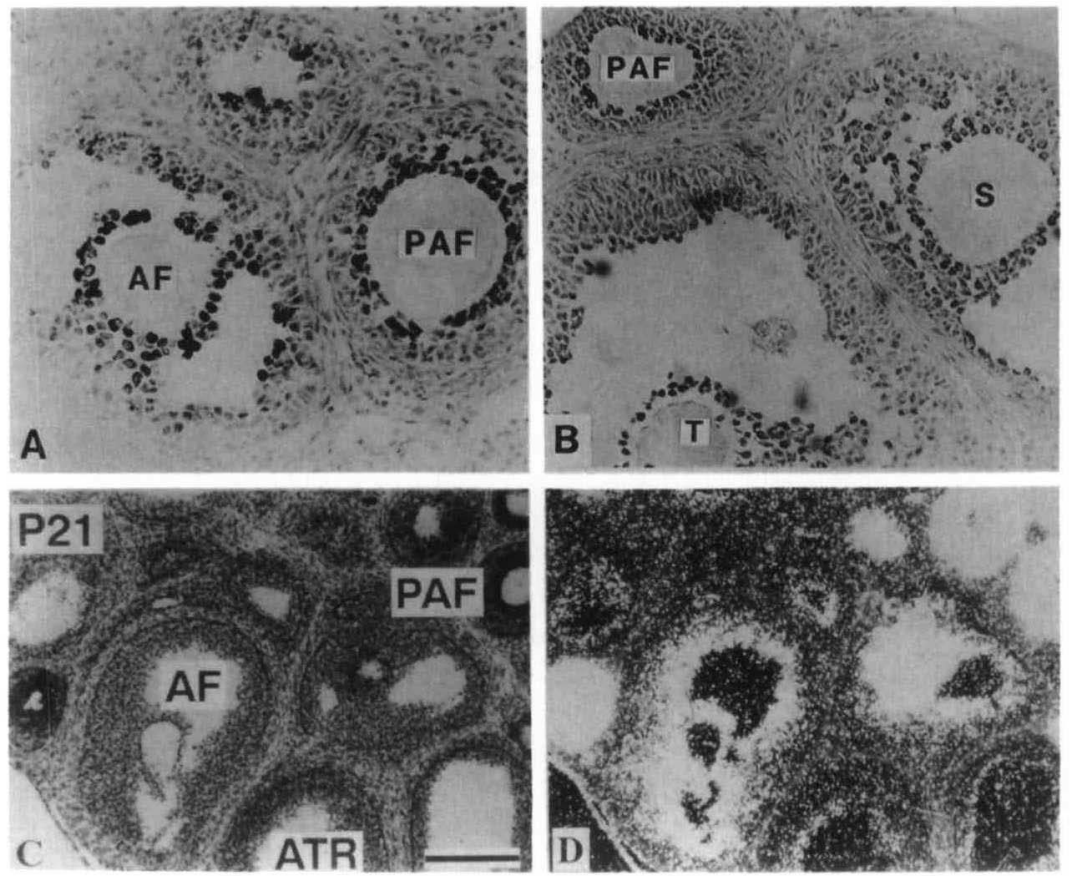

synthesis and decrease estrogen production. Another bioassay for MIS has been developed utilizing this effect of MIS (85). Fetal ovaries are incubated with MIS and $\left[{ }^{3} \mathrm{H}\right]$ androstenedione for 3 days. The aromatase activity of the gonads is quantitated by measuring the amount of $\left[{ }^{3} \mathrm{H}\right] \mathrm{H}_{2} \mathrm{O}$ generated and correlates inversely with the log concentration of MIS in the culture.

MIS continues to be produced in the testes throughout gestation while the germ cells are entering a state of meiotic and mitotic arrest. Jost first proposed that a Sertoli cell factor such as MIS might inhibit Sertoli cell mitosis and prevent germ cells from entering meiotic prophase (86). The function that MIS subserves in adult testes is still not fully understood, but studies in sex-reversed B6. Y ${ }^{\mathrm{DOM}}$ mice (21) and reports of an oocyte meiosis inhibitory effect of MIS $(58,87)$ are in agreement with a role for MIS in the control of germ cell maturation. Sex-reversed B6.Y ${ }^{D O M}$ male mice develop ovotestes with poorly organized testis chords and abnormal germ cell differentiation (21). The centrally located germ cells are arrested at the prespermatogonial prophase and are surrounded by MIS positive cells, in contrast to the polar, more mature germ cells in meiotic prophase that are surrounded by MIS negative cells. The pathogenesis of the sex reversal appears to be the delayed onset and progression of testicular differentiation with a concomitant delay in MIS expression. Although these data demonstrate the striking physical proximity of MIS with immature germ cells, a causative role for MIS in the regulation of germ cell maturation is not proven.

Purified bovine MIS, in a concentration-dependent, reversible, and CAMP-independent manner has been shown to inhibit resumption of meiosis in both denuded and $\mathrm{cu}$ mulus-enclosed rat oocytes, using germinal vesicle breakdown as a measure of meiotic division (87). Purified rhMIS has similar effects in the presence of low concentrations of
NP40, a stabilizing detergent, which may reduce the aggregation that occurs when MIS is highly concentrated by affinity chromatography. It has been argued that the inhibition of oocyte meiosis is mediated by NP-40 rather than by MIS (88); however, at the concentration used, NP-40 alone affects neither regression of the Mullerian duct nor inhibition of oocyte meiosis, while at 100 -fold higher concentrations it has expected toxicity (58). Furthermore, the reversal of the inhibitory effect of rhMIS on oocyte meiosis by anti-MIS antibody and EGF provides additional evidence of its specificity (58). MIS, therefore, may have a functional role in the control of oocyte meiosis, although the mechanism for this action remains to be elucidated. The ability of MIS to inhibit either cumulus enclosed or denuded oocytes indicates that its action on the germ cell is direct, in contrast to oocyte maturation inhibitor, which acts via cumulus cell-induced cAMP (89). The interactions of these two inhibitors of oocyte meiosis deserve further investigation. The finding that MIS may control germ cell maturation in both the male and female raises possibilities for its future development as a model for contraception. The use of MIS as a contraceptive agent would have the advantage of minimal toxicity and side effects based on the lack of systemic toxicity found in patients with MISproducing ovarian tumors who have extremely elevated serum MIS levels (as discussed below).

Other roles postulated for MIS were based on the phenotypes of transgenic mice that produce supraphysiological levels of MIS (22). The female mice have virilized external genitalia and blind-ending vaginas with no uteri or oviducts. Their gonads have cord-like structures resembling seminiferous tubules and lack germ cells. Conversely, the male transgenic mice that have the highest expression of MIS are infertile with feminized external genitalia, under-developed Wolffian structures, and germ-cell deficient, undescended 
testes. Male mice with lower levels of MIS are fertile with normal sexual development. These experiments illustrate the critical role that MIS may have in gonadal morphogenesis, which may then secondarily affect differentiation of the external genitalia. Experiments to silence the MIS gene will be helpful in delineating the critical role of MIS in normal gonadal and sexual differentiation.

\section{Lung maturation}

In humans, newborn respiratory distress syndrome secondary to pulmonary immaturity from surfactant deficiency occurs more frequently in males than females (90). Androgens have been shown to inhibit the synthesis of phosphatidylcholine, a major component of surfactant, by immature pulmonary fibroblasts (90). Because testosterone is synergistic with MIS in the organ culture assay (77), and MIS is present at high serum concentrations in the fetus during the period of late lung maturation when testosterone levels are falling, the effect of MIS on phosphatidylcholine accumulation was examined (25). Lung fragments from 17.5 day gestation female fetuses were incubated with fetal testes or ovaries, or with nanomolar concentrations of bovine MIS or picomolar concentrations of rhMIS. Both testicular fragments and purified MIS preparations suppress the accumulation of disaturated phosphatidylcholine compared to lungs cultured with ovaries or buffer. Similar experiments were repeated in vivo, by intrauterine injection of nanomolar concentrations of rhMIS in the dorsal subcutaneous tissue of 19 day gestation fetuses (26). Lungs were harvested from the treated embryos 48 and $72 \mathrm{~h}$ after the injection, then assayed for disaturated phosphatidylcholine. As compared to bufferinjected controls, the lungs of female fetuses treated with rhMIS have a marked diminution of phosphatidylcholine. As an inhibitor of surfactant accumulation in the male fetus, MIS is being further investigated as a potential culprit in the increased incidence of neonatal respiratory distress syndrome in males.

Confocal microscopy shows binding of MIS to fetal lung sections; first in punctate patches on the cell surface and perinuclear area, later in the cytoplasm and nucleus (91). The mechanism by which this large, initially membrane bound glycoprotein localizes to the nucleus remains to be elucidated but presumably occurs via a specific MIS receptor-mediated event that leads to nuclear accumulation. The finding of MIS responsivity and binding in the fetal lung provides an alternative, more easily collected source of material for the purification, characterization, and cloning of the MIS receptor.

\section{Testicular descent}

A triphasic model for descent of the testes has been proposed in which the first stage is the nephric displacement of the gonad early in embryogenesis, which occurs in both males and females. The second stage is the transabdominal movement of the testes as a result of rapid gubernacular growth, and the third stage is movement through the inguinal canal (24). The second stage is postulated to be under MIS control $(8,24)$, while the third stage is thought to be mediated by androgens. Clinical observations provided clues to the function of MIS in testicular descent. In the androgen resistance syndrome, in which androgen action is lacking but MIS action is normal, the testes have descended to the inguinal ring in the majority of affected patients and animals $(92,93)$. Conversely, in the persistent Mullerian duct syndrome, in which MIS action is lacking but androgen action is normal, the testes usually fail to descend and are abdominal in position, unless herniation occurs $(81,94)$. Interestingly, dogs with the persistent Mullerian duct syndrome, who have been shown to produce bioactive MIS, may have either scrotal or abdominal testes (78). The cryptorchidism of patients with the persistent Mullerian duct syndrome has also been attributed to mechanical restraint from the retained ductal structures, which limits movement of the testes, rather than from a direct effect of MIS (95). Male offspring of rabbits immunized against MIS during early gestation, before differentiation of the genital tracts, have persistence of the Mullerian ducts but normal testicular descent (96). These experiments, however, did not conclusively exclude a role for MIS in testicular descent because the timing of the immunization was selected to affect Mullerian development and may not have been optimal for inhibition of testicular descent.

The finding of lower MIS bioactivity in testicular biopsies of infants with cryptorchidism compared to age-matched controls support the hypothesis for a role of MIS in testicular descent (23). Patients with undescended testes have also been reported to have lower serum MIS concentrations than normals at 8 to 12 months, 2 to $3 \mathrm{yr}$, and 6-7 yr of age (97). Although these observations are consistent with a role for MIS in testicular descent, many cases of cryptorchidism are secondary to an abnormality in the transinguinal phase of testicular descent; therefore the lower MIS values may reflect degeneration or dysgenesis of the abdominal testes. Although the gubernaculum is thought to be the target organ for the MIS-mediated phase of testicular descent (24), its morphogenic movements are not well understood. Purified bovine MIS did not stimulate DNA synthesis in isolated gubernacular cells (98). The effects of MIS on the gubernaculum may be indirect or may require intact tissue rather than isolated cells. Examination of MIS receptor expression in the gubernaculum will help further define this proposed function of MIS.

\section{E. Growth inhibition of transformed cells}

The role of MIS as a fetal growth inhibitor raised the theoretical consideration that MIS might continue to act postnatally on tissues of Mullerian duct origin to suppress malignant transformation. It was further postulated that MIS might be used as a therapeutic tumor regressor to restore growth control of neoplastic cells (28). The mechanisms responsible for the process of Mullerian duct regression might provide a model for the development of targeted biological modifiers with reduced toxicity and increased specificity. Tumors from reproductive tract structures derived from the Mullerian duct were first tested as potential MIS targets. Ovarian epithelial carcinomas were studied because they histologically resemble tissues derived from the embryonic 
Mullerian ducts and arise from the surface epithelium of the ovary, a derivative of the coelomic epithelium that originally invaginated to form the Mullerian ducts. These tumors represent $95 \%$ of ovarian carcinomas in the human and occur predominantly in the postmenopausal ovary after MIS production ceases. HOC-21, a human ovarian carcinoma line, was inhibited by partially purified bovine MIS in monolayer microcytotoxicity assays (28), colony inhibition (99), and as transplants in nude mice (100). Bovine MIS also inhibited colony growth of a number of primary ovarian, endometrial, and tubal carcinomas $(4,101)$.

The method of purification of MIS may affect its activation and, therefore, has significant influence on its growth-inhibitory properties. Bovine MIS that was first lentil-lectin extracted, then purified by immunoaffinity chromatography was not cytotoxic to an endometrial cell line (102). Nanomolar concentrations of highly purified rhMIS inhibited only three of 13 primary ovarian cancer explants and one small cell carcinoma of the lung in soft agar colony-forming assays (49). The rhMIS was purified by immunoaffinity chromatography, then eluted with chaotropic salts, and was shown to be $95 \%$ pure by polyacrylamide gel electrophoresis, N-terminal amino acid sequencing, and amino acid composition analysis. Polyacrylamide gel electrophoresis analysis, however, indicated that little cleavage had occurred. Furthermore, in contrast to immunoaffinity- purified rhMIS, rhMIS purified by ion exchange and carbohydrate affinity chromatography caused significant growth inhibition of the human endometrial cell line HTB-111 implanted under the subrenal capsules of irradiated CD-1 mice (A. K. Goodman and P. K. Donahoe, unpublished data).

The purification of MIS by immunoaffinity chromatography was subsequently improved to include a simple salt elution step before acid elution of MIS (11). This preparation, freed of a co-eluting contaminant which itself stimulated growth, was found to be effective in inhibiting a variety of gynecological tumors in vivo and in vitro (27) as well as a human ocular melanoma cell line (30). When holo-MIS was cleaved with plasmin and $\mathrm{N}$ - and C-terminal fragments separated by size chromatography, the bioactive C-terminal fragment also inhibited A-431 cells in an in vitro antiproliferative assay (29). Thus, activation of MIS by proteolytic cleavage is essential for its growth-inhibitory properties. The antiproliferative activity of the C-terminal fragment is currently being examined in animal models. One limitation of using the active C-terminal domain in vivo rather than holoMIS is its rapid degradation. The $\mathrm{N}$-terminal fragment may help prolong the half-life of MIS in serum, so the optimal system may require that the cleavage and activation of MIS occur at the targeted tumor. Efforts are underway to identify the proteolytic enzyme endogenous to the urogenital ridge that cleaves holo-MIS, and to develop the most specific antiproliferative ligand for therapeutic use.

\section{Clinical Applications for Serum MIS Measurements}

\section{A. Evaluation of intersex disorders}

MIS can now be detected in serum of normal infants, children, and adults in the nanogram per $\mathrm{ml}$ range, with a sensitivity as low as 0.5 to $1.0 \mathrm{ng} / \mathrm{ml}$ (Fig. 5) (14-16). Serum concentrations of MIS in young males are $10-70 \mathrm{ng} / \mathrm{ml}$ at birth, then increase slightly during the first year. During childhood, MIS gradually decreases to the basal levels (2-5 $\mathrm{ng} / \mathrm{ml}$ ) found from adolescence through adulthood (15). In contrast to the high levels in males during infancy and early childhood, MIS is not measurable in females for several years after birth and is first detectable during the second decade. Serum MIS concentrations during the reproductive years are comparable to those seen in the adult male. Similar levels are found in adult ovarian follicular fluid harvested during procedures for in vitro fertilization (C. Richards, D. T. MacLaughlin, and P. K. Donahoe, unpublished data).

The sexually dimorphic secretion of MIS before puberty makes it a sensitive and specific marker for testicular tissue. Measurement of serum MIS may be a valuable adjunct in
Fig. 5. Graph of serum MIS concentrations in normal male and female controls from infancy to adulthood as measured by the MIS enzyme-linked immunosorbent assay. [Reprinted with permission from Hudson et al.: $J$ Clin Endocrinol Metab 70:16-22, 1990 (15). ${ }^{\circ}$ The Endocrine Society.]

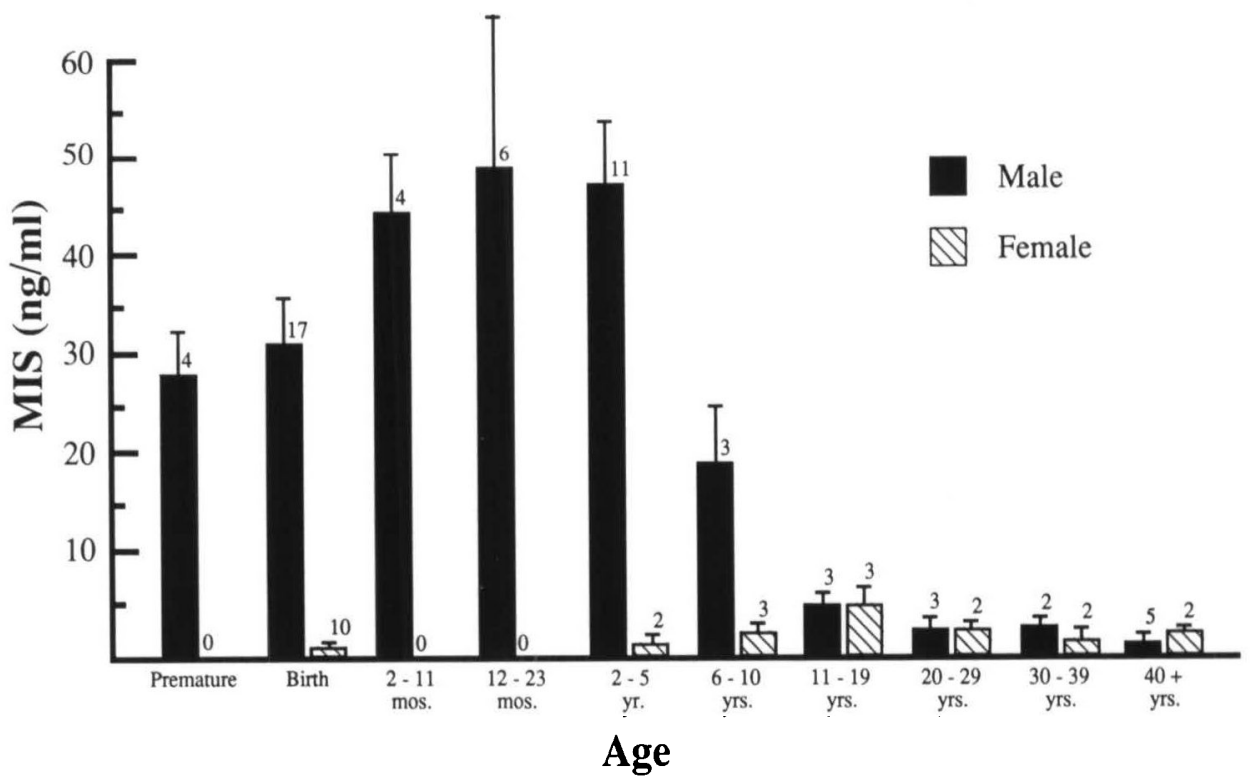


the evaluation of gonadal disorders, particularly during the neonatal and prepubertal physiological nadir of testosterone secretion when male and female testosterone levels are indistinguishable. Serum MIS concentrations have been used diagnostically to confirm the presence of testicular tissue in patients with anorchia and/or intersex anomalies $(79,80)$. MIS determination has also been useful for ensuring the complete removal of testicular tissue in the postoperative management of patients undergoing gonadectomies because of female gender assignment or potential for malignant degeneration.

\section{B. Tumor marker}

Serum MIS measurement has proven to be useful in the evaluation of selected patients with gonadal tumors. One female patient with an MIS-secreting sex cord tumor with annular tubules had serum MIS values as high as $3.2 \mu \mathrm{g} / \mathrm{ml}$ (500-1000 times normal), which decreased markedly after surgical resection (103). Her prolonged clinical course was marked by multiple tumor recurrences that correlated with elevations in MIS levels. After each resection of bulk tumor, her MIS levels decreased correspondingly. Several other patients with granulosa cell tumors have also had elevated serum MIS values that decreased after surgery $(79,103)$. Therefore, in patients with MIS-secreting granulosa or sex cord tumors, MIS measurements may serve as a predictive marker of persistent or recurrent disease.

\section{Conclusion}

MIS is a growth-inhibitory glycoprotein synthesized by Sertoli and granulosa cells that is related to the TGF $\beta$ superfamily of growth and differentiating agents. The sexually dimorphic expression of MIS at the appropriate time is essential for normal gonadal morphogenesis and sexual differentiation. Although MIS was originally defined for its role in the regression of the Mullerian ducts during normal male sexual differentiation, a large number of extra-Mullerian functions have subsequently been described. These include the regulation of germ cell maturation and gonadal morphogenesis, control of testicular descent, suppression of tumor growth, and inhibition of lung maturation. Consequently, dysregulated or abnormal expression of MIS results in disruption of both normal gonadal maturation and reproductive tract development. Much progress has been made in the understanding of the biology of MIS since it was first described almost $50 \mathrm{yr}$ ago. Further elucidation of the regulation and mechanism of action of this potent fetal growth inhibitor will provide insights concerning the control of growth and differentiation.

\section{References}

1. Jost A 1947 Recherches sur la differenciation sexuelle de l'embryon de lapin. Arch Anat Microsc Morphol Exp 36:271-315

2. Cate RL, Donahoe PK, MacLaughlin DT 1990 Mullerian inhibiting substance. In: Sporn MB, Roberts AB (eds) Peptide Growth Factors and their Receptors II. Springer-Verlag, Berlin, vol 95:179210
3. Josso N, Picard JY, Tran D 1977 The anti-Mullerian hormone. Recent Prog Horm Res 33:117-160

4. Cate RL, Ninfa EG, Pratt DJ, MacLaughlin DT, Donahoe PK 1986 Development of Mullerian inhibiting substance as an anticancer drug. Cold Spring Harb Symp Quant Biol 51:641-647

5. Donahoe PK, Cate RL, MacLaughlin DT, Epstein J, Fuller AF, Takahashi M, Coughlin JP, Ninfa EG, Taylor LA 1987 Mullerian inhibiting substance: gene structure and mechanism of action of a fetal regressor. Recent Prog Horm Res 43:431-467

6. Josso N 1986 Anti-Mullerian hormone: new perspectives for a sexist molecule. Endocr Rev 7:421-433

7. MacLaughlin DT, Epstein J, Donahoe PK 1991 Bioassay, purification, cloning, and expression of Mullerian inhibiting substance. Methods Enzymol 198:358-369

8. Hutson JM, Metcalfe SA, MacLaughlin DT, Cate RL, Cigarroa F, Ueno S, Donahoe PK 1989 Mullerian inhibiting substance. In: Burger H, de Kretser D (eds) The Testis, ed 2. Raven Press, Ltd, New York, pp 143-179

9. Josso N, Picard JY 1986 Anti-Mullerian hormone. Physiol Rev 66:1038-1090

10. Donahoe PK, Hutson JM, Fallat ME, Kamagata S, Budzik GP 1984 Mechanism of action of Mullerian inhibiting substance. Annu Rev Physiol 46:53-65

11. Ragin RC, Donahoe PK, Kenneally MK, Ahmad M, MacLaughlin DT 1992 Human Mullerian inhibiting substance: enhanced purification imparts biochemical stability and restores antiproliferative effects. Protein Expression Purif 3:236-245

12. Pepinsky RB, Sinclair LK, Chow EP, Mattaliano RJ, Manganaro TF, Donahoe PK, Cate RL 1988 Proteolytic processing of Mullerian inhibiting substance produces a transforming growth factor $-\beta$ like fragment. J Biol Chem 263:18961-18964

13. Picon R 1969 Action du testicule foetal sur le developpment in vitro des canaux de Muller chez le rat. Arch Anat Microsc Morphol Exp 58:1-19

14. Baker ML, Metcalfe SA, Hutson JM 1990 Serum levels of Mullerian inhibiting substance in boys from birth to 18 years, as determined by enzyme immunoassay. J Clin Endocrinol Metab 70:11-15

15. Hudson PL, Dougas I, Donahoe PK, Cate RL, Epstein J, Pepinsky RB, MacLaughlin DT 1990 An immunoassay to detect human Mullerian inhibiting substance in males and females during normal development. J Clin Endocrinol Metab 70:16-22

16. Josso N, Legeai L, Forest MG, Chaussain JL, Brauner R 1990 An enzyme linked immunoassay for anti-Mullerian hormone: a new tool for the evaluation of testicular function in infants and children. J Clin Endocrinol Metab 70:23-27

17. Kuroda T, Lee MM, Haqq CM, Powell DM, Manganaro TF, Donahoe PK 1990 Mullerian inhibiting substance ontogeny and its modulation by follicle-stimulating hormone in the rat testes. Endocrinology 127:1825-1832

18. Takahashi M, Hayashi M, Manganaro TF, Donahoe PK 1986 The ontogeny of Mullerian inhibiting substance in granulosa cells of the bovine ovarian follicle. Biol Reprod 35:447-453

19. Teng CS 1987 Quantification of mullerian inhibiting substance in developing chick gonads by a competitive enzyme-linked immunosorbent assay. Dev Biol 123:255-263

20. Bezard J, Vigier B, Tran D, Mauleon P, Josso N 1987 Immunocytochemical study of anti-Mullerian hormone in sheep ovarian follicles during fetal and post-natal development. J Reprod Fert 80:509-516

21. Taketo T, Saeed J, Nishioka Y, Donahoe PK 1991 Delay of testicular differentiation in the B6.Y(Dom) ovotestis demonstrated by immunocytochemical staining for Mullerian inhibiting substance. Dev Biol 146:386-395

22. Behringer RR, Cate RL, Froelick GJ, Palmiter RD, Brinster RL 1990 Abnormal sexual development in transgenic mice chronically expressing Mullerian inhibiting substance. Nature 345:167-170

23. Donahoe PK, Ito Y, Morikawa Y, Hendren WH 1977 Mullerian inhibiting substance in human testes after birth. J Pediatr Surg 12:323-330

24. Hutson JM, Donahoe PK 1986 The hormonal control of testicular descent. Endocr Rev 7:270-283 
25. Catlin EA, Manganaro TF, Donahoe PK 1988 Mullerian inhibiting substance depresses accumulation in vitro of disaturated phosphatidylcholine in fetal rat lung. Am J Obstet Gynecol 159:1299-1303

26. Catlin EA, Powell SM, Manganaro TF, Hudson PL, Ragin RC, Epstein J, Donahoe PK 1990 Sex-specific fetal lung development and Mullerian inhibiting substance. Am Rev Respir Dis 141:466470

27. Chin T, Parry RL, Donahoe PK 1991 Human Mullerian inhibiting substance inhibits tumor growth in vitro and in vivo. Cancer Res 51:2101-2106

28. Donahoe PK, Swann DA, Hayashi A, Sullivan MD 1979 Mullerian duct regression in the embryo correlated with cytotoxic activity against human ovarian cancer. Science 205:913-915

29. MacLaughlin DT, Hudson PL, Graciano AL, Kenneally MK, Ragin RC, Manganaro TF, Donahoe PK 1992 Mullerian duct regression and anti-proliferative bioactivities of Mullerian inhibiting substance reside in its carboxy-terminal domain. Endocrinology 131:291-296

30. Parry RL, Chin TW, Epstein J, Hudson PL, Donahoe PK 1992 Recombinant human Mullerian inhibiting substance inhibits human ocular melanoma cell lines in vitro and in vivo. Cancer Res 52:1182-1186

31. Massague J 1990 The transforming growth factor $-\beta$ family. Annu Rev Cell Biol 6:597-641

32. Liu MA, Oliff A 1991 Transforming growth factor- $\beta$-Mullerian inhibiting substance family of growth regulators. Cancer Invest 9:325-336

33. Derynck R, Jarrett JA, Chen EY, Eaton DH, Bell JR, Assoian RK, Roberts AB, Sporn MB, Goeddel DV 1985 Human transforming growth factor- $\beta$ complementary DNA sequence and expression in normal and transforming cells. Nature 316:701-705

34. Mason AJ, Hayflick JS, Ling N, Esch F, Ueno N, Ying S, Guillemin R, Niall H, Seeberg P 1985 Complementary DNA sequence of ovarian follicular fluid inhibin show precursor structure and homology with transforming growth factor- $\beta$. Nature 318:659663

35. Vale W, Rivier J, Vaughan J, McClintock R, Corrigan A, Woo W, Karr D, Spiess J 1986 Purification and characterization of an FSH releasing protein from porcine ovarian follicular fluid. Nature 321:776-779

36. Ling $N$, Ying SY, Ueno $N$, Shimasaki S, Esch F, Hotta $M$, Guillemin R 1986 Pituitary FSH is released by a heterodimer of the $\beta$-subunits from the two forms of inhibin. Nature 321:779782

37. Weeks DL, Melton DA 1987 A maternal mRNA localized to the vegetal hemisphere in Xenopus eggs codes for a growth factor related to TGF- $\beta$. Cell 51:861-867

38. Gelbart WM, Irish VF, St. Johnston RD, Hoffmann FM, Blackman RK, Segal D, Posakony LM, Grimaila R 1985 The decapentaplegic gene complex in Drosophila melanogaster. Cold Spring Harb Symp Quant Biol 50:119-125

39. Wozney JM, Rosen V, Celeste AJ, Mitsock LM, Whittiers MJ, Kriz RW, Hewick RM, Wang EA 1988 Novel regulators of bone formation: molecular clones and activities. Science 242:1528-1534

40. von Heijne G 1986 A new method for predicting signal sequence cleavage sites. Nucleic Acids Res 14:4683-90

41. Cate RL, Mattaliano RJ, Hession C, Tizard R, Farber NM, Cheung A, Ninfa EG, Frey AZ, Gash DJ, Chow EP, Fisher RA, Bertonis JM, Torres G, Wallner BP, Ramachandran KL, Ragin RC, Manganaro TF, MacLaughlin DT, Donahoe PK 1986 Isolation of the bovine and human genes for Mullerian inhibiting substance and expression of the human gene in animal cells. Cell 45:685-698

42. Haqq CM, Lee MM, Tizard R, Wysk M, Demarinis J, Donahoe PK, Cate RL 1992 Isolation of the rat gene for Mullerian inhibiting substance. Genomics 12:665-669

43. Munsterberg A, Lovell-Badge R 1991 Expression of the mouse anti-Mullerian hormone gene suggests a role in both male and female sexual differentiation. Development 113:613-624

44. Cohen-Haguenauer O, Picard JY, Mattei MG, Serero S, Nguyen VC, de Tand MF, Guerrier D, Hors-Cayla MC, Josso N, Frezal J 1987 Mapping of the gene for anti-Mullerian hormone to the short arm of human chromosome 19. Cytogenet Cell Genet 44:2-

45. King TR, Lee BK, Behringer RR, Eicher EM 1991 Mapping antiMullerian hormone (Amh) and related sequences in the mouse: identification of a new region of homology between MMU10 and HSA19p. Genomics 11:273-283

46. Lee MM, Cate RL, Donahoe PK, Waneck GL 1992 Developmentally regulated polyadenylation of two discrete mRNAs for Mullerian inhibiting substance. Endocrinology 130:847-853

47. Sachs A 1990 The role of poly(A) in the translation and stability of mRNA. Curr Opin Cell Biol 2:1092-1098

48. Budzik GP, Powell SM, Kamagata S, Donahoe PK 1983 Mullerian inhibiting substance fractionation by dye-affinity chromatography. Cell 34:307-314

49. Wallen JW, Cate RL, Kiefer DM, Riemen MW, Martinez D, Hoffman RM, Donahoe PK, Von HDD, Pepinsky B, Oliff A 1989 Minimal antiproliferative effect of recombinant Mullerian inhibiting substance on gynecological tumor cell lines and tumor explants. Cancer Res 49:2005-11

50. Donahoe PK, Budzik GP, Trelstad R, Mudgett HM, Fuller AJ Hutson JM, Ikawa H, Hayashi A, MacLaughlin D 1982 Mullerian-inhibiting substance: an update. Recent Prog Horm Res 38:279-330

51. Benoit R, Ling N, Esch F 1987 A new prosomatostatin-derived peptide reveals a pattern for prohormone cleavage at monobasic sites. Science 238:1126-1129

51a.Wilson CA, diClemente N, Ehrenfels C, Pepinsky RB, Josso N, Vigier B, Cate RL 1993 Mullerian inhibiting substance requires its $\mathrm{N}$-terminal domain for maintenance of biological activity, a novel finding within the transforming growth factor- $\beta$ superfamily. Mol Endocrinol 7:247-257

52. Hutson JM, Fallat ME, Kamagata S, Donahoe PK, Budzik GP 1984 Phosphorylation events during Mullerian duct regression. Science 223:586-589

53. Brautigan DL, Bornstein P, Gallis B 1981 Phosphotyrosyl-protein phosphatase: Specific inhibition by zinc ion. J Biol Chem 256:65196522

54. Donahoe PK, Budzik GP, Trelstad RL, Schwartz BR, Fallat ME, Hutson JM 1984 Molecular dissection of Mullerian duct regression. In: Trelstad RL (ed) The Role of Extracellular Matrix in Development. Alan R. Liss, New York, pp 573-595

55. Coughlin JP, Donahoe PK, Budzik GP, MacLaughlin DT 1987 Mullerian inhibiting substance blocks autophosphorylation of the EGF receptor by inhibiting tyrosine kinase. Mol Cell Endocrinol 49:75-86

56. Cigarroa FG, Coughlin JP, Donahoe PK, White MF, Uitvlugt N, MacLaughlin DT 1989 Recombinant human mullerian inhibiting substance inhibits epidermal growth factor receptor tyrosine kinase. Growth Factors 1:179-191

57. Catlin EA, Uitvlugt ND, Donahoe PK, Powell DM, Hayashi M, MacLaughlin DT 1991 Mullerian inhibiting substance blocks epidermal growth factor receptor phosphorylation in fetal rat lung membranes. Metabolism 40:1178-1184

58. Ueno S, Manganaro TF, Donahoe PK 1988 Human recombinant mullerian inhibiting substance inhibition of rat oocyte meiosis is reversed by epidermal growth factor in vitro. Endocrinology 123:1652-1659

59. Auberger P, Falquerho L, Contreves JO, Pages G, Le Cam G, Rossi B, Le Cam A 1989 Characterization of a natural inhibitor of the insulin receptor tyrosine kinase: cDNA cloning, purification and anti-mitogenic activity. Cell 58:631-640

60. Mathews LS, Vale WW 1991 Expression cloning of an activin receptor, a predicted transmembrane serine kinase. Cell 65:973982

61. Lin HY, Wang XF, Ng-Eaton E, Weinberg RA, Lodish HF 1992 Expression cloning of the TGF- $\beta$ type II receptor, a functional transmembrane serine/threonine kinase. Cell 68:1-20

62. Bercu BB, Morikawa Y, Jackson IM, Donahoe PK 1978 Increased secretion of Mullerian inhibiting substance after immunological blockade of endogenous luteinizing hormone releasing hormone in the rat. Pediatr Res 12:139-142

63. Bercu BB, Morikawa Y, Jackson IM, Donahoe PK 1979 Inhibition 
of Mullerian inhibiting substance secretion by FSH. Pediatr Res 13:246-249

64. Kuroda T, Lee MM, Hirobe S, Ragin RC, Donahoe PK 1991 Mullerian inhibiting substance production and cleavage is modulated by gonadotropins and steroids. Endocrinology 129:29852992

65. Vigier B, Picard JY, Campargue J, Forest MG, Heyman Y, Josso N 1985 Secretion of anti-Mullerian hormone by immature bovine Sertoli cells in primary culture, studied by a competition-type radioimmunoassay: lack of modulation by either FSH or testosterone. Mol Cell Endocrinol 43:141-150

66. LaQuaglia M, Shima H, Hudson P, Takahashi M, Donahoe PK 1986 Sertoli cell production of Mullerian inhibiting substance in vitro. J Urol 136:219-224

67. Voutilainen R, Miller LM 1987 Human Mullerian inhibitory factor messenger ribonucleic acid is hormonally regulated in the fetal testis and in adult granulosa cells. Mol Endocrinol 1:604-608

68. Guerrier D, Boussin L, Mader S, Josso N, Kahn A, Picard JY 1990 Expression of the gene for anti-Mullerian hormone. J Reprod Fertil 88:695-706

69. Koopman P, Munsterberg A, Capel B, Vivian N, Lovell-Badge R 1990 Expression of a candidate sex-determining gene during mouse testis differentiation. Nature 348:450-452

70. Hirobe S, He WW, Lee MM, Donahoe PK 1992 Expression of Mullerian inhibiting substance mRNA in granulosa and Sertoli cells coincides with their mitotic activity. Endocrinology 131:854862

70a.Maqq CM, King CY, Donahoe PK, Weiss MA 1993 SRY recognizes conserved DNA sites in sex-specific promoters. Proc Natl Acad Sci USA 90:1097-1101

71. Trelstad RL, Hayashi A, Hayashi K, Donahoe PK 1982 The epithelial-mesenchymal interface of the male rat Mullerian duct: loss of basement membrane integrity and ductal regression. Dey Biol 92:27-40

72. Tsuji M, Shima H, Yonemura CY, Brody J, Donahoe PK, Cunha GR 1992 Effect of human recombinant Mullerian inhibiting substance on isolated epithelial and mesenchymal cells during Mullerian duct regression in the rat. Endocrinology 131:1481-1488

73. MacLaughlin DT, Levin RK, Catlin EA, Taylor LA, Preffer FI, Donahoe PK 1992 Identification of Mullerian inhibiting substance specific binding in human cell lines. Horm Metab Res 24:570-575

74. Hayashi A, Donahoe PK, Budzik GP, Trelstad RL 1982 Periductal and matrix glycosaminoglycans in rat Mullerian duct development and regression. Dev Biol 92:16-26

75. Taguchi O, Cunha GR, Lawrence WD, Robboy SJ 1984 Timing and irreversibility of Mullerian duct inhibition in the embryonic reproductive tract of the human male. Dev Biol 106:394-398

76. Donahoe PK, Ito Y, Hendren WHI 1977 A graded organ culture assay for the detection of Mullerian inhibiting substance. J Surg Res 23:141-148

77. Ikawa H, Hutson JM, Budzik GP, MacLaughlin DT, Donahoe PK 1982 Steroid enhancement of Mullerian duct regression. J Pediatr Surg 17:453-458

78. Meyers-Wallen VN, Donahoe PK, Ueno S, Manganaro TF, Patterson DF 1989 Mullerian inhibiting substance is present in testes of dogs with persistent Mullerian duct syndrome. Biol Reprod 41:881-888

78a. Meyers-Wallen VN, Lee MM, Manganaro TF, Kuroda T, MacLaughlin D, Donahoe PK 1993 Mullerian inhibiting substance is present in embryonic testes of dogs with persistent Mullerian duct syndrome. Biol Reprod, in press.

79. Gustafson ML, Lee MM, Asmundson L, MacLaughlin DT, Donahoe PK 1993 Mullerian inhibiting substance in the diagnosis and management of intersex and gonadal abnormalities. J Pediatr Surg, $28: 439-444$

80. Josso N, Boussin L, Knebelmann B, Nihoul-Fekete C, Picard JY 1991 Anti-Mullerian hormone and intersex states. Trends Endocrinol Metab 2:227-233

81. Guerrier D, Tran D, VanderWinden JM, Hideux S, Van Outryve L, Legeai L, Bouchard M, Van Vliet G, De Laet MH, Picard JY,
Kahn A, Josso N 1989 The persistent Mullerian duct syndrome: a molecular approach. J Clin Endocrinol Metab 68:46-52

82. Knebelmann B, Boussin L, Guerrier D, Legeai L, Kahn A, Josso N, Picard JY 1991 Anti-Mullerian hormone Bruxelles: a nonsense mutation associated with the persistent Mullerian duct syndrome. Proc Natl Acad Sci USA 88:3767-3771

83. Ueno S, Takahashi M, Manganaro TF, Ragin RC, Donahoe PK 1989 Cellular localization of mullerian inhibiting substance in the developing rat ovary. Endocrinology 124:1000-1006

84. Vigier B, Watrin F, Magre S, Tran D, Josso N 1987 Purified bovine AMH induces a characteristic freemartin effect in fetal rat prospective ovaries exposed to it in vitro. Development 100:43-55

85. Vigier B, Forest MG, Eychenne B, Bezard J, Garrigou O, Robel P, Josso N 1989 Anti-Mullerian hormone produces endocrine sex reversal of fetal ovaries. Proc Natl Acad Sci USA 86:3684-8

86. Jost A 1972 A new look at the mechanisms controlling sex differentiation in mammals. Johns Hopkins Med J 130:38-53

87. Takahashi M, Koide SS, Donahoe PK 1986 Mullerian inhibiting substance as oocyte meiosis inhibitor. Mol Cell Endocrinol 47:225234

88. Tsafriri A, Picard JY, Josso N 1988 Immunopurified anti-mullerian hormone does not inhibit spontaneous resumption of meiosis in vitro of rat oocytes. Biol Reprod 38:481-485

89. Tsafriri A, Pomerantz SH 1986 Oocyte maturation inhibitor. Clin Endocrinol Metab 15:157-170

90. Torday JS, Nielsen HC, Fenel MD, Avery ME 1985 Sex differences in fetal lung maturation. Am Rev Respir Dis 123:205-208

91. Catlin EA, Ezzell R, Donahoe PK, Manganaro T, Ebb RG, MacLaughlin DT 1992 Mullerian inhibiting substance binding protein localization. Dev Dynamics (formerly Am J Anat) 193:295299

92. Hutson JM 1986 Testicular feminization: a model for testicular descent in mice and men. J Pediatr Surg 21:195-198

93. Perez-Palacios G, Jaffe RB 1972 The syndrome of testicular feminization. Pediatr Clin North Am 19:653-667

94. Brook CGD, Wagner $H$, Zachmann $M$, Prader A, Armendares S, Frenk S, Aleman P, Najjar SS, Slim MS, Genton N, Bozic C 1973 Familial occurrence of persistent Mullerian duct structures in otherwise normal males. Br Med J 1:771-773

95. Josso N, Fekete C, Cachin O, Nezelof C, Rappaport R 1983 Persistence of Mullerian ducts in male pseudohermaphroditism and its relationship to cryptorchidism. Clin Endocrinol (Oxf) 19:247-258

96. Tran D, Picard JY, Vigier B, Berger R, Josso N 1986 Persistence of mullerian ducts in male rabbits passively immunized against bovine anti-mullerian hormone during fetal life. Dev Biol 116:160167

97. Yamanaka J, Baker M, Metcalfe S, Hutson JM 1991 Serum levels of Mullerian inhibiting substance in boys with cryptorchidism. J Pediatr Surg 26:621-623

98. Fentener van Vlissingen JM, van Zoelen EJJ, Ursem PJF, Wensing CJG 1988 In vitro model of the first phase of testicular descent: identification of a low molecular weight factor from fetal testis involved in proliferation of gubernaculum testis cells and distinct from specified polypeptide growth factors and fetal gonadal hormones. Endocrinology 123:2868-2877

99. Fuller AFJ, Guy S, Budzik GP, Donahoe PK 1982 Mullerian inhibiting substance inhibits colony growth of a human ovarian carcinoma cell line. J Clin Endocrinol Metab 54:1051-1055

100. Donahoe PK, Fuller AFJ, Scully RE, Guy SR, Budzik GP 1981 Mullerian inhibiting substance inhibits growth of a human ovarian cancer in nude mice. Ann Surg 194:472-480

101. Fuller AFJ, Krane IM, Budzik GP, Donahoe PK 1985 Mullerian inhibiting substance reduction of colony growth of human gynecologic cancers in a stem cell assay. Gynecol Oncol 22:135-148

102. Rosenwaks Z, Liu HC, Picard JY, Josso N 1984 Anti-Mullerian hormone is not cytotoxic to human endometrial cancer in tissue culture. J Clin Endocrinol Metab 59:166-169

103. Gustafson ML, Lee MM, Scully RE, Moncure AC, Hirakawa T, Goodman A, Muntz HG, Donahoe PK, MacLaughlin DT, Fuller AF 1992 Mullerian inhibiting substance as a marker for ovarian sex-chord tumor. N Engl J Med 326:466-471 